\title{
Strategi Multiple Intelligences Pada Study From Home Sebagai Inovasi Mengajar Guru Selama Covid-19
}

\author{
Nur Indah Rahmawati ${ }^{1, a,}$ Citra Ayyuhda ${ }^{2, b}$ \\ ${ }^{1,2}$ Fakulatas Tarbiyah, IAIN Metro \\ Jl. Ki Hajar Dewantara 15a Kampus Kota.Metro Prov.Lampung

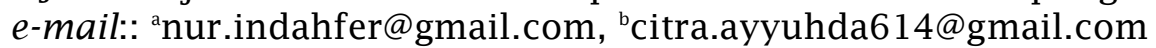

\begin{abstract}
This literature review will discuss the development of challenges or disfficultie for elementary school teachers and students during the Covid-19 Priod in dealing with change incurrent education pattens. The teacher, as the key to successful learning, seeks to increase creativity in teaching. The teacher need to increase creativity and inovasi in dealing with online learning problems. The purpose of research literature is to provide an overview of the creativity a teachers. in innovating during the distance learning process. This research uses qualitative methods with literature studies. The results also show that there is a descriptive significant difference between students' Multiple Intelligences ability with the creativity ability and teacher strategy development during learning amidst the implementation of SFH or Study From Home during the Covid-19 pandemic. Intelligence describes the individual's ability to complete tasks to achieve goals.
\end{abstract}

Keywords: Multiple Intelligences, SFH (Study From Home), Covid-19

\begin{abstract}
Abstrak
Kajian literatur ini akan membahas pengembangan tantangan dan kesulitan guru dan siswa sekolah dasar di masa Covid 19 dalam menghadapi perubahan pola pendidikan saat ini. Guru merupakan Kunci dari keberhasilan pembelajaran, berupaya untuk meningkatkan kreativitas dalam mengajar. Guru perlu meningkatkan krativitas dan inovasi dalam menghadapi permasalahan pembelajaran daring. Tujuan dari literature riset ini adalah dapat memberikan gambaran kreativitas guru dalam berinovasi pada saat proses pembelajaran jarak jauh. Riset ini memakai metode kualitatif dengan studi literature. Hasil penelitian juga menunjukkan bahwa terdapat perbedaan yang signifikan secara deskriptif antara kemampuan Multiple Intelligences siswa dengan kemampuan kreativitas dan pengembangan strategi guru selama pembelajaran ditengah-tengah dilaksanakannya SFH atau Study From Home saat pandemi Covid-19. Kercedasan menggambarkan kemampuan individu dalam menyelesaikan tugas untuk mencapai tujuannya.
\end{abstract}

Kata Kunci : Multiple Intelligences, SFH (Study From Home), Covid-19 


\section{PENDAHULUAN}

Bangsa kita saat ini masih dalam tahap proses perbaikan kualitas pendidkan guna menghadapi revolusi industri masa depan yang semakin maju. Kini bangsa Indonesia dan dunia dikejutkan dengan Virus mematikan yang berbahaya bagi manusia. Paru-paru adalah saluran pernapasan manusia yang diserang oleh virus ini. Pada umumnya masyarakat di dunia menyebutnya dengan Virus Covid-19, sedangkan WHO (Word Health Organization) mengeditifikasi virus dengan nama SARS COV-2 (Severe Acute Respirastory Syndrome Corona Virus Type 2), yaitu penyakit sindrom pernapasan akut yang disebabkan virus famili Corona virus tipe 2. [1]

Pandemi virus covid-19 ini semakin menyebar diberbagai belahan dunia dan menjadi sorotan seluruh dunia. Saat ini Indonesia merasakan dampak yang sama dengan banyaknya kasus-kasus kematian yang disebabkan Covid-19 yang semakin bertambah dan mengkhawatirkan. Dokter Ain Fen seorang dokter dari Kota Wuhan yang pertama kali menemukan Virus ini [2]. Virus Covid-19 berdasarkan informasi dari kementrian RI memiliki rata-rata masa inkubasi 5-6 hari dan terlama dari masa inkubasi adalah 14 hari. Virus Covid-19 juga mempunyai gejala-gejala awal sama dengan flu yaitu demam tinggi, batuk kering, hingga sesak nafas [3]. Sejak pertama kali Covid-19 ditemukan hingga meluar sampai keseluruh dunia hingga saat ini WHO memetapkan virus ini sebagai Pandemi Global atau Darurat Kesehatan Global.

Sampai saat ini COVID-19 masih menjadi sorotan dunia, dan masih mengamati manakah vaksin yang terbaik untuk mencegah penyebaran Covid-19 . Dalam waktu ini, Indonesia masih dalam masamasa pemberian vaksin, tetap dengan menjaga protokol kesehatan secara ketat, menjaga jarak, mencuci tangan dan memakai masker [4]

Tentunya dengan semakin digalakkannya Social Distacing atau Pembatasan Sosial dan Physical Distancing atau Pembatasan Fisik pemerintah juga melarang dengan diadakannya kegiatan 
pembelajaran, kegiatan perekonomian, dan kegiatan lain yang bersifat langsung dan dengan berkumpul. Maka pemerintah sempat mencanangkan peraturan untuk belajar Luring atau luar jaringan dengan berkelompok 2-10 siswa maksimal. Namun ternyata pandemi virus corona semakin merebak bahkan sampai ke wilayah-wilayah desa. Seperti contohnya desa Sidowaras Kecamatan Bumiratu Nuban Kabupaten Lampung Tengah.

Sebelum adanya larangan untuk bertemu secara langsung ditempat atau lembaga pendidikan seperti sekolah, masyarakat desa Sidowaras sempat beberapa kali melakukan pembelajaran secara langsung atau tatap muka dengan mematuhi protokol kesehatan yang sudah diwajibkan untuk dipatuhi oleh semua pihak sekolah khususnya di SD Negeri Sidowaras.

Pada satuan pendidikan dikarenakan pandemi Covid-19 dikengeluarkan Surat Edaran No. 3 Tahun 2020 oleh Kemendikbud RI tentang pencegahan Covid-19. Pandemi ini semakin parah sehingga memaksa merubah sistem pembelajaran demi mencegah penyebaran Covid-19 dibidang Pendidikan. Disalah satu poin dihimbau satuan Pendidikan agar menepatkan pembiasaan budaya hidup sehat dan bersih juga untuk sementara tidak melangsungkann kegiatan yang dapat berpotensi mengumpulkan banyak orang contohnya kemah, karya wisata, dan kegiatan Belajar Mengajar (KBM)[5]. Pada masa-masa seperti saat Pandemi Covid-19 diharapkan KBM tetap berlangsung dan tidak terhenti sehingga siswa tetap memperoleh pembelajaran dari guru. Oleh karena itu Pemerintah mengeluarkan satu kebijakan SFH (Study From Home) dengan menggunakan pembelajaran jarak jauh siswa tetap dapat belajar dirumah.

Ditengah-tengah merebaknya Virus Covid-19 Kemendikbud membuat kebijakan tentang aturan baru kegiatan Pembelajaran agar dapat dilaksanakan secara Daring dan Luring. Di dalam kamus besar Bahasa Indonesia menjelaskan Daring adalah jaringan terhubung melalui jaringam internet, komputer dan sebagainya, sedangkan luring adalah pembelajaran secara langsung atau tatap muka. Oleh sebab itu 
peran guru sangatlah vital dalam proses pembelajaran, bukan hanya melepas kewajibannya mengajar. Guru adalah seorang fasilitator yang mampu mengedintifikasi keunggulan dan kelemahan dari menerapkan macam-macam metode pembelajaran hingga terciptalah pembelajaran yang efektif dan menyenangkan dapat terwujud. Pada dasarnya mengajar merupakan usaha yang diciptakan dari sebuah kondisi atau sistem lingkungan dalam upaya mendukung berlangsungnya proses belajar. [6]

Pembelajaran Study Frome Home berbasis daring juga memiliki kelebihan dan kelemahan dibandingkan dengan pembelajaran tatap muka pada umumnya. Kelebihan dari Study From Home berbasis daring yang disampaikan oleh Waryanto dalam [7] yaitu mampu mengembangkan hubungan siswa dan guru yang saling berkolerasi yang dapat dilaksanakan kapanpun dan dimanapun. Selain itu pembelajaran online harus dapat menjangkau siswa dalam cangkupan yang luas dan mudah mengakses dan menyimpan materi pembelajaran.

Heru Purwono Berpendpat dalam [8] menyatakan bawasanya perangkat pembelajaran jarak jauh berbasis daring yang mengunakan sistem penugasan pada siswa menggunakan media WAG (Whatshapp Group) dianggap dalam kondidi darurat lebih efektif seperti saat dimasa pandemi Covid-19. Berbagai inovasi pembelajaran menggunakan daring telah banyak digunakan Pendidik sebagai media pembelajaran SFH. Berbagai macam upaya dilaksanakan agar siswa tidak bosan belajar dari rumah. Sudah banyak metode-metode pembelajaran yang telah digunakan oleh guru baik melaluai ceramah online, aplikasi zoom, video tutorial di youtobe, sampai dengan membuat konten pembelajaran. Selain itu saat ini guru juga menggunakan aplikasi LMS (Learning Management System) pembelajaran guna menunjang pembelajaran online.

Menurun Putra Wijaya di dalam [9] menyatakan Study Frome Home dapat dilaksanakan dengan cara efektif dan efesian menggunakan aplikasi pembelajaran daring. Kegiatan belajar mengajar 
tidak terbatas hanya pada ruang kelas saja, juga dapat dilaksanakan dilingkungan rumah dan dilingkungan masyarakat. Semuanya dapat dilaksanakan dengan baik dan lancar Semua itu dapat berjalan dengan lancar asalkan fasilitas mendukung dan cukup memadai seperti stabilnya jaringan internet.

Dizaman Revolusi Industri 4.0 seperti saat ini hampir semua menggunakan IoT (Internet of Things). Suprapto dalam penelitiannya juga menyampaikan Pembelajaran dari rumah berbasis daring dapat merangsang keinginan siswa untuk belajar tanpa batasan di tengah pandemi covid-19 saat ini [10] Berdasarkan hasil surve yang dilaksanakan Kemendikbud menunjukkan bahawa telah banyak sekolah yang susdah melaksanakan SFH melalui sistem daring, hasil itu telah mencapai 63,4\% ditahun 2020. Alasan tersebut diperkuat dengan media pembelajaran daring sangat mudah untuk diakses dan digunakan dikondisi pandemi Covid-19 saat ini [5]

SFH berbasis daring ini selain memiliki kelebihan juga mempunyai kekurangan dan hambatan dalam pelaksanaannya. Akibat dari pandemi Covid-19 pelaksanaan kegiatan pembelajaran dilaksanakan secara virtul dari sekolah dasar hingga perguruan tinggi, banyak siswa yang tidak memiliki sarana dan prasarana repersentative di rumah dalam mengakses pembelajaran jarak jauh. Tidak adanya alat penunjang yang tersedia untuk siswa dalam pembelajaran daring seperti komputer, laptop, dan smart phone yang memudahkan proses pembelajaran virtual di rumah. Hambatan laiinnya siswa belum terbiasa akan sistem pembelajaran daring. Sebab dikarenakan siswa sudah biasa dengan pembelajaran langsung secara tatap muka/konvensional [11]

Selain itu ada banyak masalah lain yang tampak saat pembelajaran daring. Pembelajaran yang sebelumnya belum tuntas diajarkan guru saat pembelajaran daring, kemudian guru mengganti tugas yang lainya. Perihal tersebut dapat menjadi masalah besar bagi siswa karna bertambah banyak tugas pemberian dari guru mengakibatkan proses pembelajaran siswa yang belum tuntas. Hal 
inipun dirasakan orang tua siswa yang kewalahan harus membagi waktu mengajari anaknya dirumah. Namun pelaksanaan pembelajaran Daring atau Study From Home sebagai langkah tepat guna sebagai langkah pencegahan dan mengurangi dampak penularan Virus Covid19. Diharapkan dengan pembelajaran daring ini siswa tidak tertinggal pelajaran yang mana telah disusum dalam Kurikulim Pembelajaran Sekolah selama setahun.

Kebijakan mengeluarkan New Normal yang pernah dikeluarkan pemerintah memiliki tujuan untuk menghidupkan kembali sektor perekonomiaan rakyat yang sudah lebih dari dua tahun kebelakangan mengalami kelumpuhan akibat dari dampak virus Covid-19. Namun khususnya sistem pendidikan dimasa pandemi di sekolah belum dapat sepenuhnya berani dibuka oleh pemerintah. Hal tersebut diakibatkan karna anak-anak usia sekolah masih cendrung labil dan belum bisa mengikuti prosedur kesehatan yang dihimbau oleh pemerintah. Anak sekolah masih senang berbaur satu sama lain sehingga dapat menyebarkan virus Covid-19 dilingkungan sekolah. Oleh karena itu pembelajaran sampai saat ini masih bersifat daring dari jarak jauh. Bagi guru tentu menjadi tantangan tersendiri dalam melaksanakan pembelajaran daring sebagai upaya mencapai hasil belajar siswa dan juga usaha dalam mendidik karakter anak bangsa.

Pendidikan Karakter dalam kehidupan bermasyarakat khususnya dikalangan remaja harus diajarkan sejak dini. Selain persoalan pembelajaran yang bersifat daring dari rumah SFH, juga semakin menurunnya kualitas moral dan karakter anak bangsa. Karakter dalam kamus besar bahasa Indonesia dapat diartikan sebagai sifat pribadi yang relatif stabil pada diri individu yang menjadi landasan penampilan perilaku dalam standar moral dan norma yang tinggi. Karakter merupakan keperibadian dan sikap seseorang yang diyakininya baik dan berwujud dalam tingkah lakunya sebagai pribadi menjadikannya memiliki reputasi baik dimata orang lain.

Pendapat ahli Berkowitz dan Bier dalam maunah menyatakan bahwa Menciptakan lingkungan sekolah melalui pendidkan karakter 
siswa merupakan upaya dalam mengembangkan rasa tanggung jawab dan etika menggunakan model pembelajaran karakter yang baik melalui nilai-nilai universal [12]. Dalam hal ini sistem pembelajaran jarak jauh berbasis daring yang dilaksanakan di luar sekolah akan menjadi tanggung jawab dan tugas ekstra bagi seorang guru untuk dapat menciptakan lingkungan pembelajaran dalam upayanya mengembangkan rasa tanggung jawab dan etika siswa.

Kendala guru melaksanakan metode evaluasi pembelajaran dari pendidikan karakter antara lain dengan observasi langsung yaitu mengamati perubahan sikap yang muncul pada diri siswa. Kendala lainya yang dihadapi guru dalam penerapan pembelajaran daring seperti guru kurang dapat menguasai teknologi, kendala laiinya tidak adanya jaringan internet dan seolah-olah inovasi dari pengintegrasian pendidikan karakter pada pembelajaran daring masih baru booming dimasa pandemi Covid-19. Berdasarkan permasalahan tersebut diatas maka penulis hendak memberikan kajian tentang studi literatur "Stategi Multipple Intelegence pada SFH study From Home sebagai inovasi bagi guru mengajar selama Covid-19". Belajar bukan hanya sekedar memberikan tugas pada siswa, namun juga mengajak guru untuk mengembangkan strategi dan inovasi dalam memberikan pembelajaran yang efektif dan menyenangkan.

\section{METODE PENELITIAN}

Penelitian ini menggunakan studi literatur dari beberapa sumber baik buku, media cetak, jurnal online maupun media elektronik yaitu metode kualitatif. Dilaksanakan pencarian Jurnal online Pencarian dengan menggunakan Google Cendikia melalui katakunci "Dampak Covid-19, Multipple Intelegences dan Implementasi Study From Home". Berdasar dari hasil pencarian yang didapat dari bermacam-macam artikel sehingga dipilih yang memenuhi kriteria yang terdapat pembahasan dampak covid, kecerdasan majemuk dan Implementasi 


\section{Hipotenusa}

Journal of Research Mathematics Education

Study From Home. Adapun teknik penelitian ini dilakukan menggunakan teknik dokumentasi yang bersifat risalah, lektur, essay, karya ilmiah, jurnal dan surat kabar. Uji validitas dengan menggunakan trigulasi sumber data. Analisis tinjauan literatur dengan 4 tahap dari mulai mengumpulkan data, mereduksi data, mendisplay data dan menarik kesimpulan. Tujuan dari penelitian ini adalah dapat dilihat dari mengembangakan pembelajaran daring bagi anak sekolah pandemi covid-19 menuju new normal. Menganalisis strategi pengintegrasian pendidikan karakter pada pembelajaran daring dengan menggunakan metode Multiple Intelligence sebagai inovasi alternative, agar proses belajar mengajar dalam memenuhi kurikulum dapat tercapai.

\section{HASIl DAN PEMBAHASAN}

Corona virus atau yang kita kenal Covid-19, berasal dari kingdom besar virus yang mengakibatka infeksi pada salur pernapasan. Virus ini dapat mengganggu pernapasan dari yang ringan seperti flu hingga sampai dengan infeksi pernapasan akut seperti Pneumonia atau radang paru-paru [13]. Untuk mencegah penyebarannya pemerintah menghimbau seluruh warga masyarakat untuk membatasi aktivitas yang berpotensi menimbulkan kerumunan semacam seperti sekolah, perkantoran, tempat-tempat beribadah dan pusat perbelanjaan atau sejenisnya. Pemerintah menganjurkan untuk warga masyarakat tetap dirumah saja work from home (WFH) atau bekerja dari rumah, study from home (WFH) atau bekerja dari rumah, beribadah dirumah dan menutup pusat-pusat perbelanjaan untuk mencegah bertambahnya korban kematian akibat Covid-19.

Bangsa Indonesia saat ini masih sedang memperbaiki kualitas Pendidikan guna menyambut era revolusi 5.0. Bangsa Indonesia bahkan dunia dikejutkan dengan penemuan virus yang muncul diawal tahun 2019 yang sangat berbahaya. Hal ini sangat mempengaruhi 
segala sektor termasuk sistem pendidikan. Pemerintah mewajibkan untuk melaksanakan pembelajaran jarak jauh bagi siswa dari sekolah PAUD hingga perguruan tinggi. Bukan hanya di Indonesia keadaan ini terjadi juaga diseluruh Negara demi mencegah penyebaran Covid-19.

SFH (Study From Home) atau pembelajaran jarak jauh pada sekolah tingkat dasar mengugunakan sistem daring atau online membutuhkan pendampingan dan bimbingan dari orang tua. Hubungan korelasi antara guru, siswa dan orang tua dilakukan dengan cara virtual atau dunia maya menggunakan perangkat berteknologi seperti komputer, laptop, notebook dan smartphone. Selain itu SFH juga menggunakan aplikasi dari pemerintah seperti aplikasi rumah belajar dan Learning Management System atau disingkat LMS. Juga aplikasi yang disedikan dari Swasta seperti Zoometing, Cisco, Whatshapps Group, Google Classroom, Google Meeting dan lainnya.

Pembelajaran dengan Luring atau Tatap Muka sudah pasti sangatlah berisiko mengingat kondisi pandemik Covid-19 yang tidak memungkinkan untuk dilaksanakan. Dengan melakukan pembelajaran daring atau pembelajaran online dapat dilaksanakan kapan saja dan dimana saja [14]. Berdasarkan hasil surve dan pengamatan untuk itu di SD Negeri Sidowaras dalam rangka mematuhi kebijakan pemerintah dalam mencegah menyebarnya virus corona maka pembelajaran pun dilakukan secara daring walaupun dalam peraturan era New Normal sempat melakukan pembelajaran Luring atau luar jaringan dengan membentuk kelompok belajar bersama dengan jumlah siswa yang sudah barang tentu dibatasi maksimal 10 orang siswa. Namun belum lama melakukan pembelajaran dengan luring atau luar jaringan yang tanpa aplikasi pembelajaran pandemik semakin merajalela sehingga program pembelajaran secara luring haruslah dihentikan.

Pada hakikatnya Pendidikan memiliki dua tujuan, yaitu mencerdaskan anak bangsa (smart) dan memiliki budi perkerti yang luhur atau baik (good). Untuk menjadikan anak yang cerdas dan pandai, bisa jadi mudah dilakukan asal tekun berlajar. Namun untuk menjadi anak yang berbudi pekerti luhur, baik dan akhlak yang terpuji 


\section{Hipotenusa}

dan moral yang sarat akan kebajikan akan dirasa lebih sulit dan bahkan tidak mudah. Oleh karena itu wajar apabila dikatakan bahwa masalah yang berkaitan dengan moral dan perilaku seseorang merupakan persoalan yang akut yang mengiringi kehidupan manusia saat ini. Dalam kehidupan masyarakat indonesis saat ini khususnya dikalangan pelajar terjadi penurunan kualitas moral sehingga menuntut diselenggarakannya pendidikan karakter.

Selain berpengaruh terhadap psikologis siswa SD Negeri Sidowaras dan tingkat sosialisasi siswa didik tetapi juga cara dan pola mengajar guru yang akan terlihat semakin monoton dengan hanya memberikan tugas dan latihan dalam bentuk perintah di aplikasaplikasi yang sudah digunakan seperti Whatssaps maupun Google Classroom. Berdasarkan hasil temuan tersebut penulis berusaha memberikan solusi sebagai strategi dalam usaha pendidikan karakter bangsa pada masa Pandemi Covid-19 yaitu dengan pendidikan karakter Multiple Intellegence pada sekolah dasar sebagai inovasi mengajar guru selama melaksanakan SFH.

Gardner dalam [15] menyatakan bahwa dia mendefinisikan kecerdasan secara lebih luas dengan menolak tradisional konsep, yang berpendapat bahwa kecerdasan manusia dapat diukur secara objektif. Gardner mengklaim bahwa kecerdasan mencakup banyak kemampuan, yang tidak dapat dijelaskan hanya dengan satu faktor, dan itu manusia tidak memiliki kecerdasan yang unik sebaliknya, semua kemampuan dan kapasitas tersebut ada di setiap manusia minimal. Gardner mengartikan kecerdasan sebagai kemampuan untuk menemukan dan memecahkan masalah dan membuat produk yang berharga dalam lingkungan budaya seseorang. Daftar karakteristik kecerdasan sebagai berikut: (1) Setiap individu memiliki kemampuan untuk memperbaiki dan meningkatkan kecerdasannya; (2) Intelijen tidak hanya dapat diubah, tetapibisa diajarkan kepada orang lain juga; (3) Kecerdasan merupakan fenomena multidimensi yang dihasilkan dari interaksidari intelek dan otak; (4) Intelijen adalah keseluruhan, lengkap dalam dirinya sendiri meskipun multidirectional; (5) Setiap individu dapat 
menjadi dominan dalam bidang kecerdasan; (6) Berbagai area beroperasi dengan satu sama lain, umumnya dalam harmoni; (7) Banyak cara agar setiap individu bisa cerdas di setiap bidang.

Berdasarkan hasil dari penelitian terdahulu yang digagas oleh [16] mengungkapkan bahwa strategi Multiple Intelegences peserta didik mampu mengembangkan delapan kecerdasannya seperti yang disampaikan oleh Dr. Horwar Gardnerd sebagai pencetusnya. Kecerdasan itu meliputi pertama, linguistic Intellegence atau kecerdasan bahasa kecerdasan ini fokus pada berfikir dalam kata-kata. Kedua, logical mathematical intelligence atau logika matematika yaitu berfikir dengan penalaran atau logika. Ketiga, visual or spasial intelligence atau kecerdasan visual-spasial yaitu berfikir dalam cerita dan gambar. Keempat, musical intelligence atau kecerdasan musical adalah berfikir dalam melodi. Kelima, Body/Kibesthetic intelligence atau kecerdasan gerak tubuh/ kinestetik yaitu berfikir melalui sensasi dan gambar gerak tubuh. Keenam natural intelligence atau kecerdasan alam yaitu berfikir dalam alam. Ketuju interpersonal intelligence atau kecerdasan sosial yaitu berfikir melalui komunikasi dengan orang lain. Kedelapan, interpersonal in intelligence yaitu berkir secara relektif. Anak diusia sekolah masih sangatlah labil mengingat tergolong remaja yang dirasa sangat penting dalam penanamkan dan pengembangkan karakter bangsa. Melalui Stategi Multiple Intelligences atau Multiple Talent Approach dapat dilakukan dengan Strategi Pendidikan Karakter. Dan berdasarkan penemuan [17]menyatakan untuk meningkatkam rasa tanggung jawab siswa dalam belajar dapat menggunakan model pembelajaran berbasis portopolio.

Hasil ini sesuai dengan [18] Penelitiannya menghasilkan temuan penting dari kelayakan strategi pembelajaran berbasis Multiple Intelligences diterapkan dalam pelajaran tentang lingkungan alam. Berdasarkan hasil penelitian dapat disimpulkan bahwa terdapat pengaruh yang signifikan terhadap metode Multiple Intelligences pada pengembangan karakter dan kecerdasan majemuk siswa sekolah. Enam tahapan proses pembelajaran berbasis Multiple Intelligences, yang 


\section{Hipotenusa}

terdiri dari (1) refleksi diri; (2) pengenalan konsep; (3) rumusan pertanyaan; (4) eksplorasi konsep; (5) pertunjukan bakat; dan (6) rumusan kesimpulan, terbukti efektif meningkatkan lima jenis kecerdasan, yaitu kecerdasan interpersonal, intrapersonal, visualspasial, kinestetik dan musik. Langkah-langkah strategi pembelajaran yang sederhana membuat strategi ini mudah digunakan di dalam kelas, tanpa harus membuatnya program khusus sebagaimana diterapkan pada penelitian sebelumnya. Hasil penelitian ini memberikan kontribusi untuk peningkatan kualitas pembelajaran yang berbasis lingkungan sekitar dan alam di masa depan. Pembelajaran tidak lagi berorientasi pada peningkatan akademik kemampuan, tetapi juga berusaha untuk meningkatkan keterampilan proses sains dan potensi siswa.

Tujuan dari penelitian ini memberikan gambaran kepada para guru atau calon guru dapat meningkatkan krativitas dan inovasi dalam proses pembelajaran dirumah agar mampu mengkomodir tujuan pebelajaran yang menyenangkan khususnya dalam pendidikan karakter bangsa. Berdasarkan Surat Edaran Mendikbud No. 4 tahun 2020 mengacu pada perinsip pelaksanaan Belajar dari Rumah (BDR) yaitu; pelaksanaan pembelajaran dilaksanakan dari rumah untuk memberi pengalaman bagi siswa belajar yang bermakna, tanpa memberi beban tuntutan menuntaskan keseluruhan capaian Kurikulum. Tugas guru dengan orang tua dan siswa adalah dapat merancang sebuah mekanisme berkomunikasi, menyusun rencana pembelajaran secara berkelanjutandan bermakna sesuai kondisi, konteks kedaerahan, karakter siswa, dan mampu berkolaborasi dengan rekan sejawat atau pihak lain dalam upaya meningkatkan kapasitas dan memastikan kelancaran proses pembelajaran. Menurut [19] guru yang hebat dan terampil adalah guru yang mampu mengajar, mendidik, menginspirasi dan menggerakan dimasa pandemi Covid-19 seperti saat ini.

Siswa Sekolah Dasar adalah usia anak yang belajar dan bermain, tak jarang mereka meluangkan waktu sedikit untuk belajar dan 
menghabiskan banyak waktu untuk bermain dirumah. Keadaan tersebut membutuhkan penyesuaian saat SFH, dimana mereka harus disiplin melaksanakan pembelajaran sesuai jadwal yang ditetapkan guru disekolah. Guru disarankan untuk berinovasi dalam pembelajaran agar tidak monoton dan membosankan, contohnya guru dapat membuat tugas dalam bentuk proyek dan guru dapat memanfaatkan aplikasi pembelajaran secara dari di rumah.

Banyak metode baru yang dapat guru lakukan dalam mengembangkan kreatifitas anak belajar bersama orang tua dirumah. Guru merencanakan pembelajaran berbasis proyek yang memanfaatkan barang bekas membuat produk bermanfaat. Sebaiknya dalam pembuatannya menggunakan alat dan bahan yang sudah tersedia di rumah, sehingga siswa atau orang tua murid tidak perlu keluar rumah untuk mencarinya. Tugas dapat dikirim melalui WhatsApp Group orang tua dan siswa. Contohnya dalam waktu dua minggu siswa ditugaskan mengerjakan tugas berbasis proyek, dalam minggu pertama siswa membuat karya dari botol bekas, botol itu boleh diwarnai, dan boleh dibuat berbagai macam bentuk. Guru memberikan contoh membentuk kotak pensil, siswa bersama orang tua diminta berkolaborasi mengembangkan kreatifitas mencari informasi diinternet dan youtobe dalam membuatnya. Contoh lainnya guru Sekolah dasar juga dapat memberikan materi pembelajaran bagi siswa dirumah

Contoh sederhana laiinnya yang dapat dilaksanaka oleh guru Sekolah Dasar dalam memberikan materi pembelajaran bagi siswa di rumah berupa cerita bergambar atau film animasi. Cerita bergambar atau film animasi tersebut berisi nilai-nilai kebaikan dan budipekerti. Melalui nilai-nilai tersebut diharapkan siswa dapat memahaminya dan mengamalkannya dalam kehidupan sehari-hari. Sehingga terpenuhilah pembelajaran dari aspek karakter bangsa.

Dengan menggunakan contoh-contoh diatas, guru dapat menggali berbagai jenis kecerdasan pada siswa. Guru juga mampu mengembangkan metode pembelajaran yang tepat agar segala aspek 
penilain dan tujuan pembelajaran dapat tercapai. Bukan hanya menilai aspek pengetahuan dan keterampilan namun juga pada aspek sikap, yang terdiri dari sikap spiritual dan sikap sosial siswa. Sikap spiritual yang dimaksud meliputi keimanan dan ketakwaan, sementara sikap sosial meliputi kejujuran, kedisipliman, kesantunan, kepercayaan diri, kepedulian dan rasa tanggung jawab. Selain itu guru juga harus dapat mengikuti perkembangan zaman yang serba digital dan menguasai IPTEK (Ilmu pengetahuan dan Teknologi).

Menyampaikan materi pembelajaran di sekolah khususnya sekolah dasar ada banyak cara yang dapat guru lakukan selama SFH atau Studi from Home. Melalui Alat Komputer, Laptop atau smartphone yang terhubung koneksi jaringan internet sistem pembelajaran jarak jauh dapat terlaksana. Guru juga dapat melaksanakan pebelajaran langsung atau tatap muka dengan menggunakan media sosial seperti aplikasi Zoom, Google Meet, WhatsApp, Telegaram, Instragram atau pembelajaran yang saat ini banyak digunakan digunakan aplikasi LMS. Sehingga guru tidak perlu merasa cemas dan dapat mematau siswa memastikan mengikuti kegiatan pembelajaran di tempat berbeda dalam waktu bersamaan. Sesuai dengan tujuan materi yang disampaikan guru dapat memberikan tugas terukur kepada siswa. Disinilah tugas seorang guru yang sangat penting adalah dapat memilih media dan metode pembelajaran yang tepat selama masa pandemi Covid-19. Dengan memilih dan menetapkan metode pembelajaran yang tepat sama artinya dengan memilih dan menetapkan tujuan pembelajaran.

Metode pembelajaran memiliki signifikansi fungsional yang kuat dan terarah dengan tujuan pembelajaran. Dengan demikian kreativitas guru dalam memilih media dan metode pembelajaran daring yang tepat menjadi bagian yang perlu diperhatikan dan sangat penting dalam menghadapi tantangan guru mengajar dimasa Covid-19. Beberapa contoh diatas bisa diterapkan untuk seluruh jenjang pendidikan tergantung bagaimana seorang guru mampu mengolah kreativitas dan inovasi pembelajaran agar menjadi terhubung antara 
guru, orang tua dan siswa agar karakter siswa dapat terbentuk walalupun dengan melakukan Study From Home.

\section{KESIMPULAN DAN SARAN}

Pembelajaran Daring adalah pilihan sistem pembelajaran yang tepat di masa Covid-19 tentu ini menjadi tantangan sendiri bagi guru sekolah dasar dalam menghadapi permasalahan selama Study From Home. Pembelajaran jarak jauh di luar lingkungan sekolah yakni daring, bagi guru merupakan tugas dan tanggung jawab eksta serta memberikan tantangan untuk mampu menciptakan lingkungan pembelajaran dalam upaya perkembangan etik, rasa tanggung jawab siswa. Kunci dari keberhasilan belajar adalah guru yang mampu memilih strategi pembelajaran yang tepat.

Strategi pembelajaran berbasis Multiple Intelligences diterapkan dalam pelajaran tentang lingkungan alam. Metode pembelajaran berbasis Multiple Intelligences memberikan pengaruh yang signifikan pada pengembangan karater dan kecerdasan majemuk siswa. Namun muncul pemasalahan guru masih kesulitan dalam inovasi pengintegrasian pendidikan karakter pada pembelajaran daring. Untuk menghadapinya guru perlu meningkatkan kreativitas dan berinovasi dalam pembelajaran Daring.

Kreativitas dan inovasi pembelajaran berkaitan dengan kemampuan guru melakukan pembenahan kelemahan prosedur atau tahapan pembelajaran, kemampuan guru dalam menciptakan perubahan model pembelajaran, kemampuan guru dalam memanfaatkan kemajuan media teknologi, kemampuan guru mengeksplolari ide baru, serta berbagai kemampuan lain yang signifikan dengan katagori guru yang kreatif dan inovatif. Harapannya kreatifitas mengajar guru yang semakin meningkat dapat menjadi solusi pembelajaran di masa pandemi Covid-19. Ide kreatif diperlukan dalam mengembangkan sistem pembelajaran daring bagi siswa selama 
SFH (study from home). Oleh karna itu guru diharapkan dapat terus mengembangkan diri dan terus meningkatkan daya kreativitas dalam mengajar selama pandemi Covid-19 yang belum berakhir.

Pembelajaran Daring masih hangat diperbincangkan dimasa pandemi Covid-19 tentu masih banyak hambatan dan kondisi yang serba terbatas dalam pembelajaran. Hal yang menjadi salah satu hambatan adalah orang tua yang harus menambah waktu mendampingi anak belajar dan berusaha memfasilitasi anak belajar dirumah. Sedangkan hambata bagi guru harus melek teknologi dan perlu banyak belajar banyak hal khususnya sistem pembelajaran Daring. Sistem pembelajaran daring ini dapat dijadikan bahan model pembelajaran dipembelajaran selanjutnya.

\section{DAFTAR PUSTAKA}

[1] Y. Pakpahan, R., \& Fitriani, “Analisa Pemanfaatan Teknologi Informasi dalam Pembelajaran Jarak Jauh di Tengah Pandemi Virus Covid-19," Anal. Pemanfaat. Teknol. Inf. dalam Pembelajaran Jarak Jauh di Teng. Pandemi Virus Covid-19, vol. Vol. 4, No, 2020.

[2] Y. Yuliana, "Corona Virus Diseases (Covid-19): Sebuah Tinjauan Literatur," vol. Vol. 2, No, 2020.

[3] Kemenkes, "Pertanyaan dan Jawaban terkait Corona Virus Diseanse Updete 6 Maret," https://covid19.kemkes. go.id, 2020. .

[4] T. . Aditama, "Covid-19 dalam Tulisan Prof. Tjandra," 2020.

[5] Kemendikbud, "Kesiapan Satuan Pendidikan Di Sekolah Dasar dalam Menghadapi Covid-19," Tim Fungsi Tata Kelola Direktorat SD Kemendikbud.," http://ditpsd.kemdikbud.go.id, 2020. .

[6] A. M. Sardiman, Interaksi \& Motivasi Belajar Mengajar. Jakarta: PT. Raja Grafindo Persada., 2020.

[7] I. W. Widiana, I. N. Jampel, and I. P. Prawini, "The Effectiveness of Traditional Game-Based Communication Learning Activity for 
Cognitive Process Dimension Learning Achievement," Cakrawala Pendidik., vol. 37, no. 2, pp. 445-448, 2018.

[8] H. Irawan, "Inovasi Pendidikan Sebagai Antisipasi Penyebaran Covid-19. Ombusman Republik Indonesia Kantor Perwalilan Propinsi Bengkulu," https://ombudsman.go.id, 2020. .

[9] H. Herliandry, L. D., Nurhasanah, N., Suban, M. E., \& Kuswanto, "Pembelajaran Masa Pandemi Covid-19. Jurnal Teknologi Pendidikan," J. Teknol. Pendidikan, vol. Vol. 22, N, 2020.

[10] Suprapto, "Belajar Tanpa Batas Saat Wabah Corona Melanda - LPMP DKI Jakarta. LPMP DKI Jakarta," https://lpmpdki.kemdikbud.go.id, 2020. .

[11] P. B. Purwanto, A., Pramono, R., Asbari, M., Hyun, C. C., Wijayanti, L. Y., Putri, R. S., \& Santoso, "Dasar, Studi Eksploratif Dampak Pandemi Covid -19 Terhadap Proses Pembelajaran Online di Sekolah," J. EduPsyCouns J. Educ. Psychol. Caunseling, vol. Vol. 2, No, 2020.

[12] B. Maunah, "Implementasi Pendidikan Karakter Dalam Pembentukan Kepribadian Holistik Siswa," J. Pendidik. Karakter, vol. Nomor 1, 2015.

[13] A. Fadli, "Mengenal Covid-19 dan Cegah Penyebaran dengan 'Peduli Lindungi' Aplikasi Berbasis Android," PKM Jur. Tek. Elektro Univ. Jendral Soedirman, 2020.

[14] G. I. Zahara, Z., \& Kirilova, "Impact of Corona Virus Outbreak Towards Teaching and Teaching and Learning Activities in Indonesia,” SALAM J. Sos. dan Budaya Syar'i, vol. Vol. 7, No, 2020.

[15] M. Agustin, "Mengenali dan Mengembangkan Potensi Kesedasan Jamak Anak Sejak Dini Sebagai Tonggak Awal Melahirkan Generasi Emas," J. Pendidik. Anak Usia Dini, vol. Vol. 4, No.

[16] N. Omeri, "Pentingnya Pendidikan Karakter dalam Dunia Pendidikan," MAPEN: Jurnal Manajer Pendidikan," J. Manajer Pendidik., vol. Vol. 9, No, 2020.

[17] S. Andrianti, "Pendekatan Model Pembelajaran Berbasis Portopolio dalam Meningkatkan Tanggung Jawab sebagai Mahasiswa di 


\section{Hipotenusa}

Journal of Research Mathematics Education

Sekolah Teologi," Dunamis; J. Teknol. Pendidik. Kristiani, vol. Vol. 3, No, 2019, doi: 10.30648/dun.v3i2 .188.

[18] A. Winarti, atiek,. Rahmini, Ani., Almubarak, "Keefektifan Collaborative Problem Solving Berbasis Multiple Intelligences Untuk Meningkatkan Keterampilan Berpikir Kritis," J. Pendidik. Penelit. Inov. Pembelajaran, vol. Vol 3 No 2, 2019, doi: https://doi.org/10.21831/jk.v3i2.24714.

[19] Lw. N. P. S. pendidikan S. D. U. dwijendra Anggraini, "Pendidikan Di sekolah dasar dalam Rangka menyongsong kenormalan baru.," 2020. 